\title{
Vestium or Ruthenium - What Does a Study of the Literature Tell Us?
}

\author{
Roman Edmund Sioda*
}

\begin{abstract}
The process of the discovery of the sixth new element and metal present in raw platinum ore granules, and called vestium or ruthenium, took place between 1807 and 1844. The element was first discovered by the Polish chemist and medical doctor, Jędrzej Śniadecki, professor at Vilnius University, presently Lithuania. It took almost 40 years to confirm the discovery by two German chemists working in Russia, Gottfried Osann and Carl Ernst Claus, who had at their disposition platinum ore recently discovered in the Ural Mountains. The discovery work of Jędrzej Śniadecki was supported by his older brother Jan Śniadecki, a noted mathematician and astronomer, who was also the Rector of Vilnius University at the time of the original discovery. Śniadecki brothers were educated in Poland (Poznań and Cracow) and abroad: Jędrzej in Pavia (Italy), Edinburgh (Scotland) and Vienna, and Jan in Göttingen, Leiden, Utrecht and prerevolutionary Paris.
\end{abstract}

Keywords: History of chemistry · Ruthenium · Śniadecki, Jan · Śniadecki, Jędrzej · Vestium

The Nobel Prize in chemistry in 2010 was awarded to the American Richard Heck and two Japanese scientists Ei-ichi Negishi and Akira Suzuki for the development of organic synthesis reactions catalyzed by metallic palladium.

In this connection, it is worth mentioning the great Polish chemist, medical doctor and biologist Jȩdrzej Śniadecki (1768-1838), born near the town of Żnin in the Province of Kujawy, educated at the Universities of Cracow, Pavia - Italy, Edinburgh - Scotland, and Vienna.

After returning to Poland he was appointed in 1797 as professor of chemistry at the University of Vilnius, Lithuania, and took up chemical research there. Already in 1800, he published in Vilnius a Polish textbook entitled: 'The Beginnings of Chemistry', which had two more editions, in 1807 and 1816. This textbook contained extensive information about inorganic and organic chemistry - information that reflected the state of chemical knowledge in Europe at that time.

This was a period of very rapid development of chemical sciences, which occurred at about the time of the publication in Paris,

\footnotetext{
${ }^{*}$ Correspondence: Prof. Dr. R. E. Sioda Institute of Chemistry of the Military University of Technology

ul. Gen. Sylwestra Kaliskiego 2

00-908 Warszawa 49, Poland

E-mail: rsioda@wat.edu.pl
}

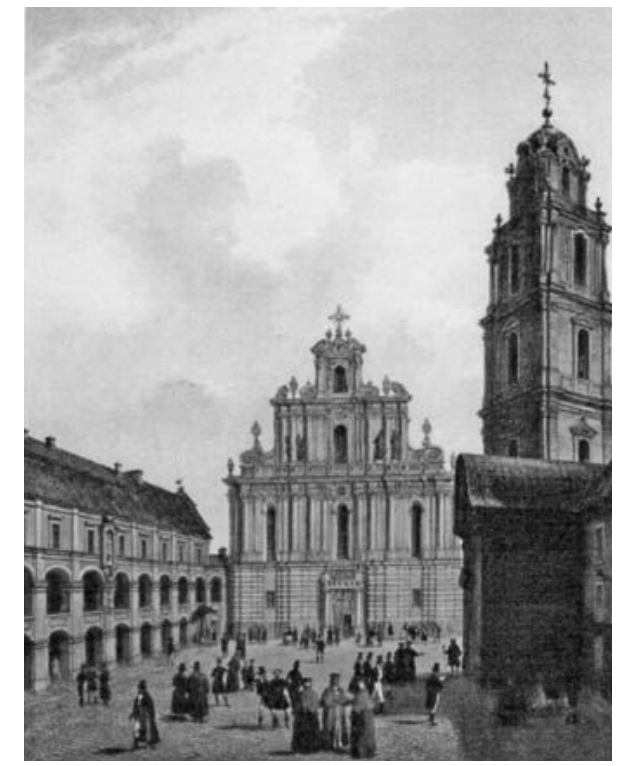

The Great Courtyard of the Vilnius University and the University Church of St. Johns. According to 'Album Wileński' by J. Wilczyński, 1850.

in 1789 and 1787 , of two important books, respectively: 'Traité de chimie' (Chemical Primer) by Antoine-Laurent de Lavoisier (1743-1794) and 'Méthode de nomenclature chimique' (Method of Chemical Nomenclature) by L.-B. Guyton de Morveau, C. L. Berthollet, A.-F. de Fourcroy and once again the eminent chemist Lavoisier. These books contributed greatly to the development of modern chemical thought and research in Europe. Jȩdrzej Śniadecki was already educated in the spirit of modern chemistry, and applied its lessons in his chemical research in Vilnius.

In the same period, many new chemical elements were discovered. An important raw material for the discovery of

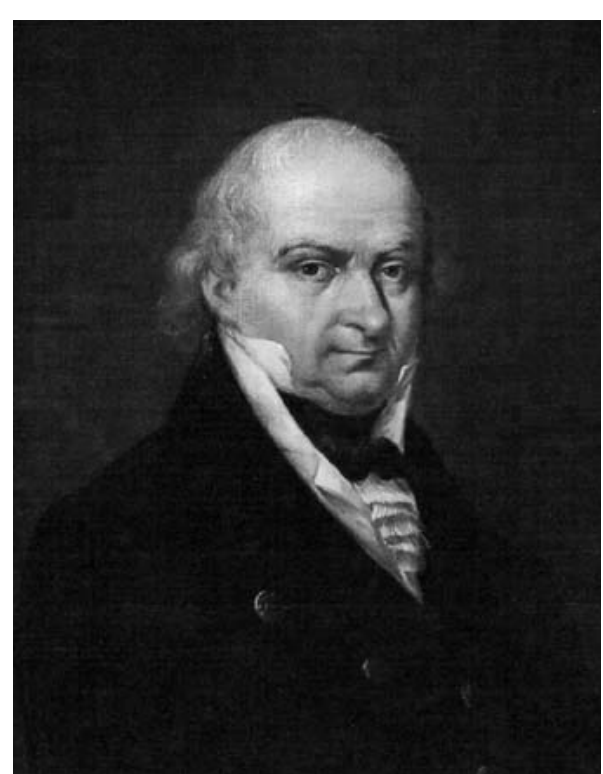

The portrait of Jędrzej Śniadecki by Vilnius painter Aleksander Sleńdziński (1803-1873) from 1843.

new elements was crude platinum from South America. In the years 1803-1804, two chemists in London, Smithson Tennant and William Wollaston, discovered in it, four new elements, namely, iridium, osmium, palladium and rhodium. Similar research was conducted in Paris, but these studies did not result in an announcement of new elements.

Jȩdrzej Śniadecki was involved in the study of crude platinum in 1806-1808 and published in Vilnius in Polish a report in a booklet entitled: 'Treatise on a new metal discovered in raw platinum', and delivered a lecture on the same subject at the University of Vilnius. In this work, he repeated the reactions described by the two English 


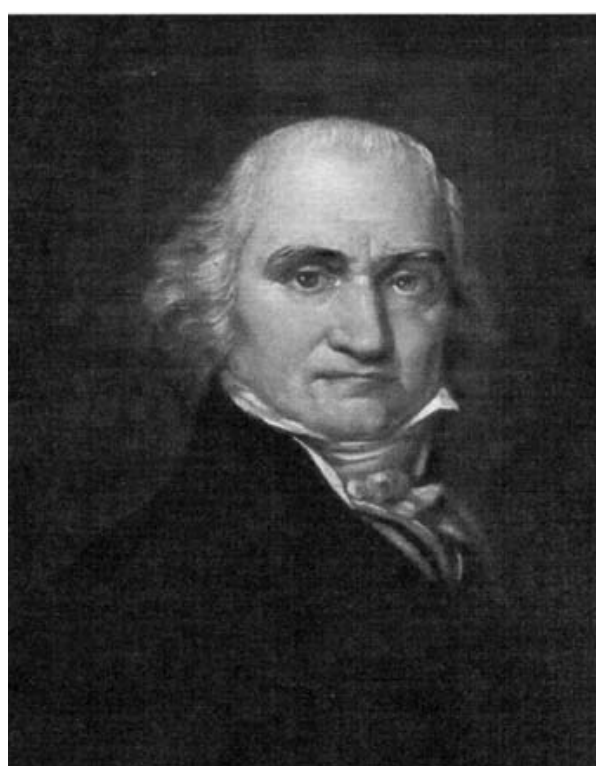

The portrait of Jan Śniadecki by the Vilnius University professor and painter Jan Rustem (1762-1835) from 1823.

chemists and chemists in Paris, identified the above-mentioned four metals of interest, and in addition discovered a new metallic element, which he called vestium to commemorate the discovery of the asteroid Vesta in 1807. An important conclusion from the work of Śniadecki was the fact that the platinum extracted earlier was not a pure metal, because it contained the element vestium, even after the removal of iridium, osmium, palladium and rhodium from the crude platinum as demonstrated a few years earlier.

Jędrzej Śniadecki found his discovery important enough to notify immediately chemists in Europe.

It so happened that at that time, Jan Śniadecki (1756-1830), Jędrzej's older brother, was the Rector of Vilnius University. He was an internationally known mathematician and astronomer, educated in Paris by renowned mathematicians and scholars Jacques Antoine Joseph Cousin (1735-1800) and Jean-Baptiste le Rond d'Alembert (1717-1783), and the fine poet l'Abbé Jacques Delille (1738-1813). Jan travelled widely in Europe, was interested in the natural sciences including chemistry, and was elected a corresponding member of the St. Petersburg Academy of Sciences in 1808 .

Jan Śniadecki was interested in the education and later career of his younger brother, first at high school and during his university studies in Cracow. Jȩdrzej attended the famous school, which is still active today, called the Nowodworski School (Nowodworek) in Cracow, and being a very capable student, received a gold medal from the Polish King Stanisław August Poniatowski (1732-1798) during his visit to the school. Later on, thanks to the efforts of Jan, Jędrzej obtained the position of chemistry professor at the University of Vilnius. The two brothers came from a wealthy family, and their father had a large estate, consisting, inter alia, in the possession of a brewery. Jan, who was actively involved with the National Education Commission, was also professor of mathematics and astronomy at the University of Cracow in the years 1781-86, and the organizer and director of the astronomical observatory there in 1792 to 1803 . He became the Rector of the University of Vilnius in the years 1807 to 1815 , when his brother Jędrzej was a professor there. Jan ran a very extensive correspondence with important people, such as Prince Adam Jerzy Czartoryski, Minister of Foreign Affairs of the Tsar Alexander I in St. Petersburg in the years 1804-06, and from 1803 to 1824 the educational curator of the Wilno district. He published his astronomical observations in Warsaw, St. Petersburg and Berlin.

It seems that Jan was instrumental in spreading the news in Europe of Jędrzej's discovery of vestium. The French Institute in Paris noted on 11 July 1808 that Jan Śniadecki delivered a communication on his astronomical observations. On the same day, the President of the meeting, Professor Jean Baptiste Joseph Delambre (1749-1822), in the presence of prominent members of the Institute, announced the arrival of the report by Jȩdrzej Śniadecki on the discovery of a new element vestium in crude platinum. The report of Jȩdrzej was read at the meeting a week later on July 18, 1808. A committee was appointed of four distinguished Parisian chemists Claude Louis Berthollet (1748-1822), Antoine-Francois comte de Fourcroy (17551809), Louis-Bernard Guyton de Morveau (1737-1816) and Louis Nicolas Vauquelin (1763-1829) - who were to repeat the experiments of Jędrzej Śniadecki, and evaluate the correctness of his discovery. ${ }^{[1]}$

The discovery of Jȩdrzej Śniadecki was briefly announced in a well-known popular-science journal in Paris, Journal de Physique, de Chimie, d'Histoire Naturelle et des Arts, in the July 1808 issue. Unfortunately, the good news in Paris ended there. It seems that the French Institute did not return to the discovery of Jędrzej Śniadecki in their reports, while the abovementioned French journal published in the issue of January 1809, a brief note that the discovery of vestium could not be repeated and further research was needed.

It is interesting that an abbreviated version of the Polish report of Jędrzej Sniadecki, translated into Russian, appeared in the popular-science journal Tekhnologicheskii Zhurnal in St. Petersburg, in the last of the four issues for the year 1809. This work was never revoked, nor caused any discussion. Tekhnologiczeskii Zhurnal was one of two major popular-science journals, published by the St. Petersburg Academy of Sciences since 1804. ${ }^{[2]}$

The Warsaw community was also informed of the discovery by the first page article in the Supplement to the Gazeta Warszawska (Warsaw Newspaper) Ad $N^{r u m}$ (No.) 62, Warsaw, on Tuesday, 2nd August 1808. Here is the text of the article entitled 'From Vilnius: 14 July' (translated from the old Polish see Figure):

"His Excellency Jędrzej Śniadecki, Professor of medicine and chemistry at the local University, working for more than six months on a thorough analysis of raw platinum to separate all metals that chemists found in the powder of Platinum, and to know their characters; discovered in this Platinum one more metal that nobody yet found, which he called Vestium from the newly invented planet called Vesta; so, what all Chemists had hitherto considered to be pure platinum, Professor of Chemistry in Vilnius showed to be a composition of two separate and different metals, that is, Platinum and Vestium, of which the specific properties he determined so that he for the first time showed the new metal Vestium and the true Platinum, and described them separately. This important invention was communicated in the past month to the National Institute in Paris, and to the Academy of Sciences in St. Petersburg. The history of his whole work, containing many new facts hitherto unknown in Chemistry, this same Author read in a hearing at an open session of his University on June 28, V. S. (Veteris styli - Latin the 'old style', i.e. according to the Julian calendar - Author's note) at the close of the courses of public lessons and the start of vacations. This dissertation is in print, and when becomes published, will be sent to the Warsaw Society of Friends of Science."

The above article stresses the importance of the discovery, whereby, in addition to the discovery of a new metal, it shows that only platinum obtained by Jȩdrzej Śniadecki was the pure metal, whose characteristics, as well as those of the new metal, he had correctly determined. The discovery was reported to the French Institute, i.e. the Academy of Sciences in Paris, the Academy of Sciences in St. Petersburg in Russia, while the Society of Friends of Sciences in Warsaw was to receive a copy of the report, after it was printed in Vilnius. The report, having 27 printed pages, was published in Vilnius by Józef Zawadzki, Vilnius University Ordinary Printer. The title page does not show the date of printing, but mentions the position of Jẹdrzej Śniadecki, as 'Doctor of Philosophy and Medicine, Ordinary and Public Professor of Chemistry at the Imperial Vilnius University, a Member of the Royal Society of 


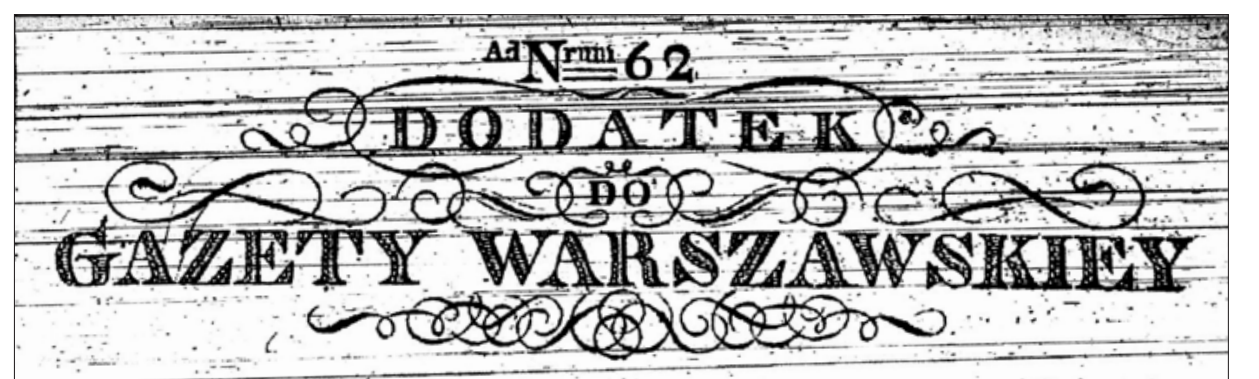

Z WARSZAWY DNIA 2 SIERPNIA R' 1808 . WE WTOREK,

$Z$ Warsxawy a. Siorpnia.

JW. Merszalek Puhstwa Xizite d'Ausr. städt, poirchul do Ralisua, dte-adbycis-rewit naddywtzy woysk Polokich, pod dowdjztwem Generals dywizyi Zaiqczka zestnigecuy.

Trzy regimenti piechoty Potskiey, ktd. re przechodza w sfuébeg Francuzks, w dninch 4 7. 6.m. marsz swdy rozpoczny do Francyt. Duin wezorayszego JO. Xiqzo Minister Woypy, otworzyl w tuteyszym arsenale ozkoIt zakisdairy Art, lleryi i Indzyniardir. Czynnost ta odprawila siz a príyzwoity uroczy. atobeis; - o ezym- w przyszley grzecio ob. merniey doniesiemy $z$ Wilna: $x_{4}$ Lipea.

JPan Jędrzey Sn iadecki, Professor me: dycyny Thimii w Uniurersytecie tuteyızym praetige przez 6 przeszlo miesiegcy. nad do-

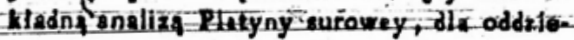
lenla wszystkich metallow, Ktdre chimicy w proszku-Pigtyny analizli i poznenta. ich cherskterdw; Odkryl w teyze Plotynie ieszeze ieden metal od nikogo nie postrzetony, ktd. ry ad nowo wyaziezionego Planety Vista mazwat Voitum, to wipa, co irazyscy dound Chimicy mieli za Platyne czysta, Pro. fissor Chimii w. Winis pokezal, ke to iest kompozycyz $z$ dodch oddzielnych i róknych metalldw, to iest Platyny $+V_{\text {est }}$, ktdrych wlasnotci charaktierystycane determinowis. tak, if on piescrszy i novey metal. Kostjum. i. prawdzlwa Rlotýne dopiera pokazal it opit int. Waeny teo wnolazek przeszlym

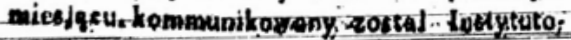

wi Narodowemu w Payzir, i Alademli naul: Peterzburgskiay. Histoiys zat eulych swo-

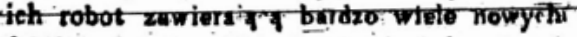
faktew dotyd w Chimii nieznanyrh, czytat: tente Autor - rorprawie swoley na posiedze:niu publicznym Uniwersyteta 28 Czerwcen V.S. prry zambrigeiu-bufsow tekryi pubtio eznych $\mathrm{i}$ rozpoczegciu wakacyi. Tha Toz frawa iest w druku i skoro wyidzie na iow, będzie postena Towarzystura. Warsiawskie mu-proyiaciol natk. 2 Noapolu 7 Liper. Statut Honstytucying Xrotloxtwo Neapolitant skiego + Sycyliyskiego (Ukotezenti.) Tyzal $V-O$ urzednikach Xorony: Art: I) Wiolkiemi, urzęnikanri. Kom ronnemi s3: Wielkj Jalmutnik, wielki Szamr. belan, wielki Marazalek, wielki Konluszy. welki Lowezy, wialki Martrz obrzydowy. Urzedy ich as doty yrotnie: 2) Szambelinnowie, Koniuszowie, Prefakci. Palacowi- ag urzędrikami kotonnemi. 3.) Kray utrzymule: korpus zlutony za 4,000 ludzi: dia struilys Krolewakiey.

Tytul VI - O Ministerizim:

Art: x.) Siedmiu jeit Ministrdw; to iest: Minister sprowiedliwosci i religiyny, Minister intersssow zagranicznych, Miniater wewnetrany; Minister skarbowy. Minister wos lenny i morski, Minister policyi'generginey;

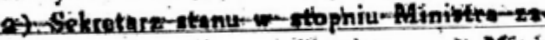
Striadczst bedzie waystlie alts. 5 ) Minis stowie sq odpowiedzialnemi za zachowenies

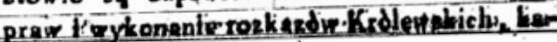
idy. $z$ swoioge wydrialuin:

The first page of the Supplement to Gazeta Warszawska of 2nd August 1808, with the correspondence from Vilnius from 14th July 1808 about the discovery of vestium by Professor Jedrzej Śniadecki. The translation of the correspondence is in the accompanying text of the article.

Friends of Science in Warsaw and of Medical Society in Vilnius', and announces that the report was 'Read at the Public meeting of the Imperial Vilnius University on the 28th Day of June 1808. d.s.' It should be mentioned here that the date shown is expressed according to the Julian (Russian) calendar. It corresponds to 10th July, 1808, in the present, Gregorian, calendar. ${ }^{[3]}$

The information about the discovery of Jȩdrzej Śniadecki in the Journal de Physique, de Chimie, d'Histoire Naturelle et des Arts in Paris reads in the issue of July 1808, Volume 67, p. 71 (Author's translation from French):

"A NOTE

About Vestium, a new metal, discovered in platinum.
They write from Germany, that a chemist discovered a new metal in granular platinum. He called it Vestium in the name of Vesta, the last planet discovered by Olbers. As the result, grains of platinum contain, $1^{\circ}$. Platinum. $2^{\circ}$. Palladium. $3^{\circ}$. Rhodium. $4^{\circ}$. Osmium. $5^{\circ}$. Iridium. $6^{\circ}$. Vestium. One extracts from it moreover, gold, iron, copper, titanium....

And in the issue of January 1809, Volume 68, p. 29 (Author's translation from French):

"Mineralogy.

About Vestium.

It concerns the naming of a new metal, which is said to be extracted from grains of raw platinum; however, these experi- ments have not yet been reproduced: so, one should wait for new research."

This journal, containing scientific reviews, was established in the 1770s. It was edited and published in Paris by JeanClaude Delamétherie (1743-1817), a naturalist, geologist, and mineralogist, who supported the French Revolution.

As mentioned above, prominent Parisian chemists such as Vauquelin, Fourcroy and Hippolyte-Victor Collet-Descotils (1773-1815) competed with British chemists for the discovery of new elements in crude platinum. British chemists emerged victorious. It is hard to believe that the French chemists were willing to accept the discovery of Jędrzej Śniadecki, when they themselves were not able to detect effectively the presence of new elements in crude platinum. However, as follows from the published Polish report of Jędrzej Sniadecki, he was aware of the work of the English and French chemists on the analysis of raw platinum. At the beginning of his report, he lists the names of the chemists, and cites some of the results of their analyses. In one of articles, the French chemists reported that they isolated red crystals, which could not be identified. It seems that Jȩdrzej Śniadecki knew about this result, and, in his report, described vestium as giving red crystals of a chloride salt. So, in a manner bolder than the said French investigators, he decided to announce his discovery of a new element. In addition he sent his findings to the assessment of Parisian chemists to compare with theirs.

In his analysis of crude platinum, Jȩdrzej Śniadecki identified palladium previously obtained by Wollaston in 1803. The properties of palladium described by Śniadecki were in full agreement with the properties given by Wollaston. In this way, Jędrzej Śniadecki was the first Pole, and Polish scholar, to study this important metal, and, quite literally, had the metal 'in his own hand'. Two hundred and two years later, three chemists were awarded Nobel Prize for research using this metal as catalyst in the synthesis of important organic compounds, including drugs.

It is not entirely clear from where the raw platinum had come, which was investigated by Jȩdrzej Śniadecki. It seems that, like the raw platinum, which was studied by the French and English chemists, it came from South America, probably Peru. However, the Napoleonic wars that took place also on the world's oceans and in the colonies, probably hindered the delivery of crude platinum to Europe. Thus, the research on raw platinum was discontinued, until platinum ore was rediscovered on the eastern slopes of the Ural Mountains in Russia. This occurred some time after 1819 or in the early 1820 s. From these new ores platinum was commercially extracted, 


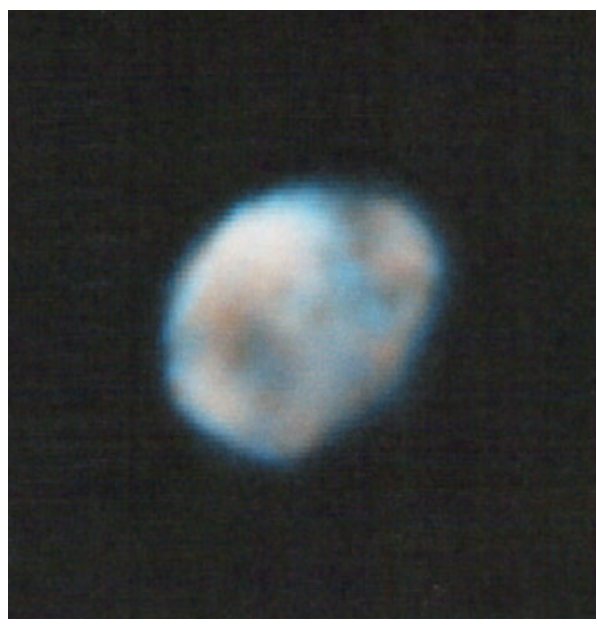

Asteroid Vesta. A photo taken on the 14th and 16th of May 2007 by Hubble Wide Field Planetary Camera 2 for NASA. In public domain.

and was used for the production of jewelry and, temporarily, coins. These ores, and especially the waste after extracting platinum, were studied by two chemists of German origin, Gottfried Osann (17961866), working at the Universities of Tartu (formerly Dorpat) in Estonia and Würzburg in Germany, and Carl Ernst Claus (1796-1864) from Tartu, who worked at the University of Kazan in Russia. They managed to extract a new element, which they named ruthenium in honour of the Old Russia (Ruthenia in Latin). Osann did his work in 1828, while Claus made his discovery in 1844. Claus obtained a few grams of ruthenium, examined its chemical properties in depth, and measured the atomic mass. ${ }^{[4]}$ In all likelihood vestium and ruthenium are the same element.
Both Śniadecki brothers co-operated closely in their research. Jan was, after the German physician and self-made astronomer, Heinrich Wilhelm Olbers (1758-1840), co-discoverer of the asteroid Pallas in 1802. Previously in 1803, the two Swedish chemists Wilhelm Hisinger (1766-1852) and Jöns Jakob Berzelius (1779-1848) called their newly discovered metallic element cerium after the asteroid Ceres detected on 1 st January 1801, and also Wollaston called his new metal palladium, after the asteroid Pallas discovered one year before. In a similar manner, Jȩdrzej Śniadecki named the new metal vestium after the asteroid Vesta, discovered in the previous year. In this way, the lifelong and fruitful cooperation between the two brothers combined their individual academic interests in astronomy and chemistry. Jẹdrzej Śniadecki was the first Pole to examine the element palladium, whose counterpart in the starry sky was co-discovered by Jan Śniadecki, as the asteroid Pallas! Discovery of vestium by Jȩdrzej Śniadecki was confirmed by Osann and Claus, as the new element ruthenium, many years later.

\section{Acknowledgements}

The author is very grateful to the following colleagues for their graceful help with acquiring copies of books or articles, which served to prepare this review article: Prof. Emeritus William H. Brock, Prof. Roald Hoffmann, Dr. Zbigniew Wielogórski, Mr. Piotr Staniak. Mr. Dave Bade, Mr. John Tebo and Mr. W. John Michalski of Library of Congress, Washington, D.C.

Received: January 17, 2011; revised February 26, 2011
[1] Institut de France, Académie des sciences, Procès-verbaux des Séances de l'academie tenues depuis la fondation de l'Institut jusqu' au mois d'août 1835, Tome IV, an 1808-1811, Hendaye (Basses-Pyrénées), 1913, http:// gallica.bnf.fr/ark:/12148/bpt6k3297q.r=.langFR.

[2] A. Sniadecki, 'O nowom metale, najdjenom w zjernach Platiny (About a new metal, found in grains of platinum)', Technologiczeskii Zhurnal 1809, 6(4), 81-98.

[3] J. Śniadecki, 'Rosprawa o nowym metallu $w$ surowey platynie odkrytym (Dissertation on a new metal discovered in raw platinum)', Józef Zawadzki, printer, Wilno, 27 pp.

[4] V. N. Pitchkov, 'The discovery of ruthenium', Platinum Metals Rev. 1996, 40(4), 181-188.

\section{General reading:}

M. Baliński, 'Życie Jędrzeja Śniadeckidego (Life of Jędrzej Śniadecki)', Ernest Günther Publisher, Leszno i Gniezno, 1840, http://bcpw.bg.pw.edu.pl/ dibra/doccontent $?$ id $=283 \&$ from $=\&$ dirids $=1 \&$.

O. E. Zvyagintsev, 'Istoria uralskoj platiny (History of platinum in Urals)', Trudy Instituta Istorii Estestvoznaniya i Tekhniki, 1955, 6, 160-204.

A. F. Kapustinskii, 'Andrei Sniadeckii i wilenskaya szkola chimikow (Jędrzej Śniadecki and the Vilno school of chemists)', Trudy Instituta Istorii Estestvoznaniya i Tekhniki, 1956, 12, 22-39.

M. E. Weeks, 'Discovery of the Elements', 7th ed., J. Chem. Edu. Washington, D.C., 1968, pp. 418-431.

M. Balasiewicz, Przemyst Chemiczny 2008, 87, 812-815.

R. E. Sioda, Przemyst Chemiczny 2010, 89, 1158

R. E. Sioda, Wiedza i Życie Feb. 2011, No. 914, pp. 41-45

R. E. Sioda, Wiadomości Chemiczne 2011, 65, 151155. 